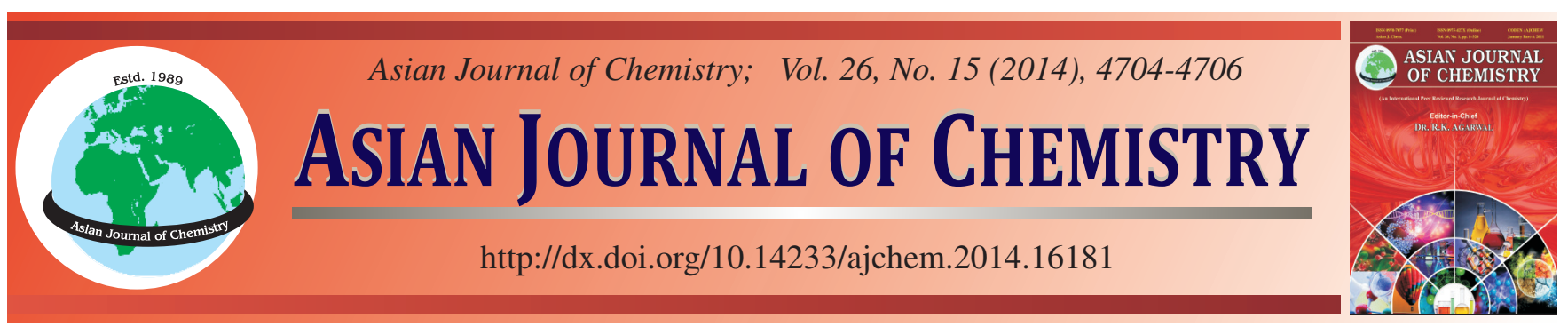

\title{
A New Phenolic Compound from the Roots of Flue-Cured Tobacco and Its Anti-Tobacco Mosaic Virus Activity
}

Wenxiu Xu ${ }^{1,2}$, Yi Han $^{2}$, Xia Zhang $^{2}$, Zhangyu Chen $^{2,3}$, Guangyu Yang ${ }^{2}$, Yadong Guo $^{1, *}$ and Yongkuan Chen ${ }^{2, *}$

${ }^{1}$ School of Pharmaceutical Science \& Yunnan Key Laboratory of Pharmacology for Natural Products, Kunming Medical University, Kunming 650500, P.R. China

${ }^{2}$ Key Laboratory of Tobacco Chemistry of Yunnan Province, Yunnan Academy of Tobacco Science, Kunming 650106, P.R. China

${ }^{3}$ China Tobacco Yunnan Industry Company (Ltd.), Kunming 650000, P.R. China

*Corresponding authors: E-mail: yadong_guo@yahoo.com.cn; cyk1966@163.com

\begin{abstract}
A new phenolic compound, (6S)-6-(4-(hydroxymethyl)-2-methoxyphenyl)-6-methoxy-2-methylheptan-1-ol (1), was isolated from the roots of flue-cured tobacco (a variety of Nicotiana tabacum $L$ ). Its structure was elucidated by spectroscopic methods, including extensive 1D and 2D NMR techniques. Compound 1 was tested for its anti-tobacco mosaic virus (anti-TMV) activity and it shows potential antitobacco mosaic virus activity with inhibition rates of $16.4 \%$.
\end{abstract}

Keywords: Phenolic compound, Flue-cured tobacco, Structure elucidation, Anti-tobacco mosaic virus activity.

\section{INTRODUCTION}

The flue-cured tobacco is a type of cigarette tobacco. It belongs to the plants of Nicotiana genus. Along with burley tobacco, it accounts for more than $90 \%$ of world tobacco production $^{1,2}$. In addition, it is also used as insecticide, anesthetic, diaphoretic, sedative and emetic agents in Chinese folklore medicine due to it containing many useful chemical compounds ${ }^{1,3-5}$. Previous phytochemical studies of flue-cured tobacco have shown the presence of terpenoids ${ }^{6-8}$, alkaloids ${ }^{9,10}$, lignans ${ }^{11,12}$, flavonoid ${ }^{13}$, phenylpropanoids ${ }^{14}$ and the homologous. The roots of flue-cured tobacco are big amount of byproduct in tobacco planting and are normally used as organic fertilizer. The multipurpose utilization of the roots of fluecured tobacco is an interesting topical and receives more and more attentions ${ }^{15-17}$. Motivated by a search for new bioactive metabolites from this plant, our group has investigated the chemical constituents of the roots of flue-cured tobacco. As a result, a new phenolic compound (1) was isolated. This article deals with the isolation, structural elucidation and the antitobacco mosaic virus (anti-TMV) activity of this new compound.

\section{EXPERIMENTAL}

Optical rotations were measured with a Horiba SEPA300 polarimeter. UV spectra were obtained using a Shimadzu UV-2401A spectrophotometer. IR spectra were obtained in
$\mathrm{KBr}$ disc on a Bio-Rad Wininfmred spectrophotometer. ESIMS were measured on a VG Auto Spec-3000 MS spectrometer. ${ }^{1} \mathrm{H},{ }^{13} \mathrm{C}$ and 2D NMR spectra were recorded on Bruker DRX500 instrument with TMS as internal standard. Column chromatography was performed on silica gel (200-300 mesh), or on silica gel H (10-40 $\mu \mathrm{m})$, Qingdao Marine Chemical Inc., China). Preparative HPLC was used an Agilent 1100 HPLC equipped with ZORBAX-C ${ }_{18}(21.2 \mathrm{~mm} \times 250 \mathrm{~mm}, 7 \mathrm{~mm})$ column and DAD detector.

The roots of flue-cured tobacco were collected in Yuxi Prefecture, Yunnan Province, People's Republic of China, in September 2011. The identification of the plant material was verified by Prof. Yuan N (Yunnan University of Nationalities).

Extraction and isolation: The air-dried and powdered roots of flue-cured tobacco $(1.8 \mathrm{~kg})$ were extracted four times with $70 \%$ aqueous acetone $(3 \times 2.5 \mathrm{~L})$ at room temperature and filtered to yield a filtrate. The crude extract (105 g) was applied to silica gel (200-300 mesh) column chromatography, eluting with a chloroform-acetone system (20:1, 9:1, 8:2, 7:3, $6: 4,5: 5)$, to give six fractions A- F. The further purification of fraction A (20:1, 8.26 g) by silica gel column chromatography, eluted with petroleum ether-acetone $(9: 1,8: 2,7: 3,6: 4,5: 5$, 0:1), yielded mixtures A1-A5. Fraction A1 (9:1, $1.06 \mathrm{~g})$ was subjected to preparative HPLC $\left(75 \% \mathrm{MeOH}-\mathrm{H}_{2} \mathrm{O}\right.$, flow rate $12 \mathrm{~mL} / \mathrm{min}$ ) to yield compound $\mathbf{1}(11.2 \mathrm{mg})$. 
(6S)-6-(4-(Hydroxymethyl)-2-methoxyphenyl)-6methoxy-2-methylheptan-1-ol (1): $\mathrm{C}_{17} \mathrm{H}_{28} \mathrm{NaO}_{4}$; obtained as yellow gum; $[\alpha]_{\mathrm{D}}^{24.5}+8.6(\mathrm{c}=0.1, \mathrm{MeOH}) ; \mathrm{UV}\left(\mathrm{CH}_{3} \mathrm{OH}\right), \lambda_{\max }$ $(\log \varepsilon) 285$ (3.64), 226 (3.85) 210 (4.22) nm; IR (KBr, $v_{\max }$, $\mathrm{cm}^{-1}$ ) 3325, 2962, 2871, 1630, 1576, 1467, 1268, 1157, 1052, 857, 762; ${ }^{13} \mathrm{C}$ NMR and ${ }^{1} \mathrm{H}$ NMR data $\left(\mathrm{CDCl}_{3}, 500\right.$ and 125 $\mathrm{MHz}$ ) (Table-1); postive ESIMS $m / z, 319[\mathrm{M}+\mathrm{Na}]^{+}$; postive HRESIMS $m / z 319.1880\left[\mathrm{M}+\mathrm{Na}^{+}\right.$(calcd. for $\mathrm{C}_{17} \mathrm{H}_{28} \mathrm{O}_{4} \mathrm{Na}$, 319.1885).

\begin{tabular}{|c|c|c|}
\hline \multicolumn{3}{|c|}{$\begin{array}{c}\text { TABLE-1 } \\
{ }^{1} \mathrm{H} \text { NMR AND }{ }^{13} \mathrm{C} \text { NMR DATA OF } \\
\text { COMPOUND } 1\left(\mathrm{CDCl}_{3}, \delta, \text { ppm, J/HZ) }\right.\end{array}$} \\
\hline No. & $\delta_{\mathrm{C}}(\mathrm{m})$ & $\delta_{\mathrm{H}}(\mathrm{m}, J$ in $\mathrm{Hz})$ \\
\hline 1 & $126.2 \mathrm{~s}$ & \\
\hline 2 & $158.2 \mathrm{~s}$ & \\
\hline 3 & $113.6 \mathrm{~d}$ & $6.71, \mathrm{~d}(1.8)$ \\
\hline 4 & $141.8 \mathrm{~s}$ & \\
\hline 5 & $117.9 \mathrm{~d}$ & $6.80, \mathrm{dd}(7.8,1.8)$ \\
\hline 6 & $127.6 \mathrm{~s}$ & 7.12, d (7.8) \\
\hline 7 & $82.2 \mathrm{~s}$ & \\
\hline 8 & $41.5 \mathrm{t}$ & $1.80, \mathrm{~m}$ \\
\hline 9 & $21.5 \mathrm{t}$ & $1.32, \mathrm{~m}, 1.15, \mathrm{~m}$ \\
\hline 10 & $36.3 \mathrm{t}$ & $1.25, \mathrm{~m}$ \\
\hline 11 & $35.5 \mathrm{~d}$ & $1.52 \mathrm{~m}$ \\
\hline 12 & $68.2 \mathrm{t}$ & $3.36 \mathrm{~m} ; 3.28, \mathrm{dd}(10.4,6.4)$ \\
\hline 13 & $18.8 \mathrm{q}$ & $0.80, \mathrm{~d}(6.8)$ \\
\hline 14 & $28.0 \mathrm{q}$ & $1.56, \mathrm{~s}$ \\
\hline 15 & $65.3 \mathrm{t}$ & 4.60 brs \\
\hline 2-OMe & $55.9 \mathrm{q}$ & $3.78 \mathrm{~s}$ \\
\hline 7-OMe & $52.2 \mathrm{q}$ & $3.28 \mathrm{~s}$ \\
\hline
\end{tabular}

\section{RESULTS AND DISCUSSION}

The air-dried and powdered roots of flue-cured tobacco $(1.8 \mathrm{~kg})$ was extracted with $70 \%$ aqueous acetone $(3 \times 2.5 \mathrm{~L})$ at room temperature and filtered to yield a filtrate, which was successively evaporated under reduced pressure to obtained a crude extract (105 g). This crude extract was subjected repeatedly to column chromatography on Silica gel, Sephadex LH-20, RP-18 and preparative HPLC to afford the new compound (1). The structures of the compound $\mathbf{1}$ were as shown in Fig. 1 and its ${ }^{1} \mathrm{H}$ and ${ }^{13} \mathrm{C}$ NMR data were listed in Table-1.<smiles>COc1cc(CO)ccc1[C@@](C)(CCC=C(C)CO)OC</smiles>

Fig.1. Structure of compound 1

Compound 1 was obtained as a pale yellow gum with the molecular formula $\mathrm{C}_{17} \mathrm{H}_{28} \mathrm{O}_{4} \mathrm{Na}$ indicating four degrees of unsaturation, which was confirmed by HRESIMS at $\mathrm{m} / \mathrm{z}$, $319.1880[\mathrm{M}+\mathrm{Na}]^{+}$(calcd. for $\mathrm{C}_{17} \mathrm{H}_{28} \mathrm{NaO}_{4}, 319.1885$ ). The UV spectrum exhibited absorptions at 226 and $285 \mathrm{~nm}$ suggesting an aromatic chromophore. The IR spectrum displayed absorption for a benzene ring $\left(1630,1576,1467 \mathrm{~cm}^{-1}\right)$ and a hydroxyl group $\left(3325 \mathrm{~cm}^{-1}\right)$, respectively. Analysis of ${ }^{13} \mathrm{CNMR}$ and DEPT spectra of $\mathbf{1}$ showed 17 carbons including one quaternary oxygenated aromatic carbon, two quaternary aromatic carbons, three tertiary aromatic carbons, one quaternary oxygenated carbon, two secondary oxygenated carbon, two methoxy, three methylene, one methine and two methyl groups. The ${ }^{1} \mathrm{H}$ NMR spectra displayed an $\mathrm{ABX}$ system of an aromatic ring $\left[\delta_{\mathrm{H}} 7.12(\mathrm{~d}, J=7.8 \mathrm{~Hz}, \mathrm{H}-6), 6.71(\mathrm{~d}, J=1.8\right.$ $\mathrm{Hz}, \mathrm{H}-3), 6.80$ (dd, $J=7.8,1.8 \mathrm{~Hz}, \mathrm{H}-5)$ ], one methoxy group $\left(\delta_{\mathrm{H}} 3.78 \mathrm{~s}\right)$, one hydroxymethyl group $\left(\delta_{\mathrm{H}} 4.60 \mathrm{brs}\right)$ and an (6S)-6-methoxy-2-methyl-heptan-1-ol structure unit $\left[\mathrm{CH}_{2} \mathrm{OHCH}\left(\mathrm{CH}_{3}\right)\left(\mathrm{CH}_{2}\right)_{3} \mathrm{C}\left(\mathrm{CH}_{3}\right)\left(\mathrm{OCH}_{3}\right)-\right]^{18}$. The ${ }^{13} \mathrm{NMR}$ data of C-7-C-14 also supported the existence of (6S)-6-methoxy2-methyl-heptan-1-ol structure unit. The methoxy group located at $\mathrm{C}-2$ was supported by the HMBC correlation (Fig. $2)$ of methoxy proton signal $\left(\delta_{\mathrm{H}} 3.78\right)$ with $\mathrm{C}-2\left(\delta_{\mathrm{C}} 158.2\right)$. The HMBC correlations of $\mathrm{H}-15\left(\delta_{\mathrm{H}} 4.60\right)$ with $\mathrm{C}-3\left(\delta_{\mathrm{C}} 113.6\right)$, C-4 $\left(\delta_{\mathrm{C}} 141.8\right)$ and C-5 $\left(\delta_{\mathrm{C}} 117.9\right)$, of H-3 $\left(\delta_{\mathrm{H}} 6.71\right)$ and H-5 $\left(\delta_{\mathrm{H}} 6.80\right)$ with $\mathrm{C}-15\left(\delta_{\mathrm{C}} 65.3\right)$ suggested the hydroxymethyl group should be located at $\mathrm{C}-4$. The (6S)-6-methoxy-2-methylheptan-1-ol structure unit located at $\mathrm{C}-1$ was supported by the HMBC correlations of one $\mathrm{H}-8\left(\delta_{\mathrm{H}} 1.80\right)$ with $\mathrm{C}-1\left(\delta_{\mathrm{C}} 126.2\right)$ and of H-6 $\left(\delta_{\mathrm{H}} 7.12\right)$ with C-7 $\left(\delta_{\mathrm{C}} 82.2\right)$. The $S$-configuration of C-7 was also supported by its optical rotation data $[\alpha]^{24.5}+8.6$. Consequently, compound 1 was elucidated as (6S)-6-(4-(hydroxymethyl)-2-methoxyphenyl)-6-methoxy-2-methylheptan-1-ol.

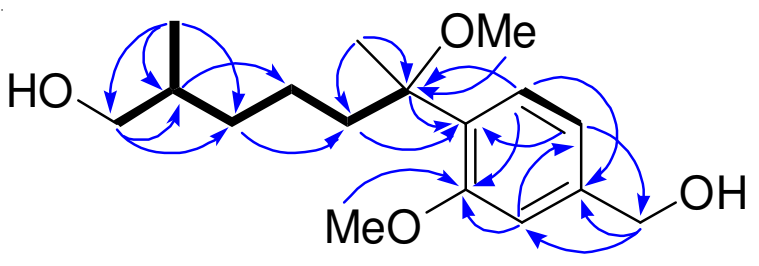

Fig.2. Key HMBC ( $)$ ) $1 \mathrm{H}-1 \mathrm{H} \operatorname{COSY}(\boldsymbol{-})$ correlations of $\mathbf{1}$

Since certain of the phenolic compounds exhibit potential Anti-TMV activity ${ }^{19-21}$, compounds $\mathbf{1}$ was tested for it antitobacco mosaic virus activity. The anti-TMV activities were tested using the half-leaf method ${ }^{21}$. Ningnanmycin ( $2 \%$ water solution), a commercial product for plant disease in China, was used as a positive control. The results showed that compound 1 exhibited inhibition rates of $16.4 \%$.

\section{ACKNOWLEDGEMENTS}

This project was supported financially by the Basic Research Foundation of Yunnan Tobacco Industry Co. Ltd (2012JC01), the National Natural Science Foundation of China (No. 21002085), the Excellent Scientific and Technological Team of Yunnan High School (2010CI08).

\section{REFERENCES}

1. The Editorial Committee of the Administration Bureau of Flora of China, Flora of China, 67 vols., Beijing Science and Technology Press, Beijing (2005).

2. T.W. Hu and Z. Mao, Tob. Control, 15(suppl_1), i37 (2006).

3. A. Rodgman and T.A. Perfetti, The Chemical Components of Tobacco and Tobacco Smoke. CRC Press, Taylor and Francis Group, Boca Raton, Florida (2008).

4. A.P. Cavender and M. Alban, J. Ethnobiol. Ethnomed., 5, 3 (2009).

5. A. Inta, P. Shengji, H. Balslev, P. Wangpakapattanawong and C. Trisonthi, J. Ethnopharmacol., 116, 508 (2008). 
6. X. Feng, J.-S. Wang, J. Luo and L.-Y. Kong, J. Asian Nat. Prod. Res., 12, 252 (2010)

7. Y. Shinozaki, T. Tobita, M. Mizutani and T. Matsuzaki, Biosci. Biotechnol. Biochem., 60, 903 (1996).

8. T. Pettersson, A.M. Eklund and I. Wahlberg, J. Agric. Food Chem., 41, 2097 (1993).

9. X.C. Wei, S.C. Sumithran, A.G. Deaciuc, H.R. Burton, L.P. Bush, L.P. Dwoskin and P.A. Crooks, Life Sci., 78, 495 (2005).

10. T. Braumann, G. Nicolaus, W. Hahn and H. Elmenhorst, Phytochemistry, 29, 3693 (1990).

11. Y.K. Chen, X.S. Li, G.Y. Yang, Z.Y. Chen, Q.F. Hu and M.M. Miao, J. Asian Nat. Prod. Res., 14, 450 (2012).

12. Q.-F. Hu, G. Yang, X. Li, X. Yang, H. Mu, Y. Chen and X.-M. Gao, Heterocycles, 85, 147 (2012).

13. Z.Y. Chen, J.L. Tan, G.Y. Yang, M.M. Miao, Z.Y. Chen and T.F. Li, Phytochem. Lett., 5, 233 (2012).

14. Y. Chen, T. Li, Z.-Y. Chen, G. Yang, M. Miao and J. Tan, Heterocycles, 83, 2381 (2011)
15. W. Li, L.B. Zhang, J.H. Peng, N. Li and X.Y. Zhu, Ind. Crops Prod., 27, 341 (2008).

16. Q. Hu, M. Miao, W. Zhao, T. Zhang, L. Wan, G. Yang, Y. Chen and D. Mou, Heterocycles, 85, 2485 (2012).

17. W.H. Zhong, C.J. Zhu, M. Shu, K.D. Sun, L. Zhao, C. Wang, Z.J. Ye and J.M. Chen, Bioresour. Technol., 101, 6935 (2010).

18. Y.M. Chung, C.K. Wei, D.W. Chuang, M. El-Shazly, C.T. Hsieh, T. Asai, Y. Oshima, T.J. Hsieh, T.L. Hwang, Y.C. Wu and F.R. Chang, Bioorg. Med. Chem., 21, 3866 (2013).

19. J.X. Chen, H.Q. Leng, Y.X. Duan, W. Zhao, G.Y. Yang, Y.D. Guo, Y.K. Chen and Q.F. Hu, Phytochem. Lett., 6, 144 (2013).

20. Q.F. Hu, B. Zhou, J.M. Huang, X.M. Gao, L.D. Shu, G.Y. Yang and C.T. Che, J. Nat. Prod., 76, 292 (2013).

21. Q.F. Hu, B. Zhou, X.M. Gao, L.Y. Yang, L.D. Shu, Y.Q. Shen, G.P. Li, C.T. Che and G.Y. Yang, J. Nat. Prod., 75, 1909 (2012). 